\section{MENUJU PARADIGMA PENDIDIKAN ISLAM TRANSFORMATIF}

\section{Imam Hanafi}

Alumni Program Pasca Sarjana UIN Suska Riau E-mail:nafie_ihsan@yahoo.co.id

\section{Abstract}

Paradigm of Islamic Transformatif Education: A critical comment proposed to education is on its teaching pattern. The teachers are regarded as being the center of knowledge (teacher-oriented). In fact, the task of the teacher is to stimulate the students' potency. Islamic education also has been criticized as exclusive. This paper tries to introduce a new 'color' in an islamic teaching by using 'transformative approach'. This means that an education should regard an academic approach, not a bureaucracy approach;support the students to look for the knowledge, not wait for knowledge;propose student-oriented, not teacher and state-oriented; stimulate active students,not passive students; put the students as theocentric-anthropocentric, not anthropocentric alone; manage de-centralistic schools, not centralistic schools; inclusive, integral, and bolistic teaching, not dogmatic teaching.

Keywords : Education, Transformatif, Islamic Education.

\section{Pendahuluan}

Inti dari cita-cita pendidikan, terutama pendidikan agama Islam adalah terbentuknya manusia yang beriman, cerdas, kreatif, dan memiliki keluhuran budhi. Tugas utama pendidikan adalah upaya secara sadar untuk mengantarkan manusia pada cita-cita tersebut, dan pendidikan Islam juga memiliki fungsi mengarahkan kehidupan dan keberagamaan manusia kearah kehidupan Islami yang ideal. ${ }^{1}$ Jika upaya pendidikan mengalami kegagalan dalam mengantarkan manusia kearah cita-cita manusiawi yang bersandar pada nilai-nilai ke-Tuhanan, maka yang akan terjadi adalah tumbuhnya prilaku-prilaku negatif dan

${ }^{1}$ Abdul Munir Mulkhan, Paradigma Intelektual Muslim: Pengantar Filsafat Pendidikan dan Dakwah, (Yogyakarta: SIPRESS, 1993), hlm. 237.
Imam Hanafi, Menuju Paradigma Pendidikan Islam Transformatif

destruktif, seperti kekerasan, radikalisme, fundamentalisme, dan terorisme, juga ketidakpedulian sosial, yang semuanya itu mengakibatkan penderitaan semesta.

Berbagai prilaku-prilaku destruktif tersebut, yang sering muncul dinegara Indonesia, merupakan akibat dari belum munculnya pribadipribadi cerdas, kreatif, dan berbudi luhur. Orang yang cerdas selalu menggunakan daya nalar manusiawinya secara benar dan obyektif dalam melihat realitas sosial. Orang yang kreatif, mempunyai pilihanpilihan dalam memenuhi dan menjawab persoalan-persoalan hidupnya. Orang yang 'Arif (seakar kata dengan 'Urf, tradisi) dan luhur budi (dalam bahasa agamanya al-Akhlâq al-Karîm), mampu menentukan pilihan yang paling tepat dan selalu menolak cara-cara kekerasan dalam mensikapi berbagai dilemma kehidupan. Kecerdasan dan kearifan yang bersumber pada daya kritis atas nilai diri dan sosial, sehingga mampu memberikan sinaran yang selalu tumbuh terhadap kepedulian pada sesama. ${ }^{2}$

Dalam konteks inilah, pendidikan agama Islam sebagai salah satu media penyadaran umat, dihadapkan pada problem begaimana mengembangkan sebuah pola pendidikan yang transformative, sebuah pola pendidikan yang mampu memberikan pemahaman dan transformasi pembelajaran yang tidak saja bertumpu pada transfer pengetahuan saja, tetapi juga transef nilai. Pendidikan transformative juga megasikan akan pola pembelajaran yang hanya berpusat pada guru (teacher centerd), tetapi lebih pada pola pembelajaran yang memberikan "ruang" bagi peserta didik untuk lebih mengaktualisasikan potensi akademisnya secara maksimal.

\section{Pendidikan Islam Tranformatif vs. Konvensional; Sebuah Pemetaan Awal}

Istilah pendidikan Islam konvensional dipakai untuk menunjukkan pola dan praktek pendidikan yang berjalan secara monoton, top-down, guruisme, sentralistik, uniform, eksklusif, formalis,

2Abdul Munir Mulkhan, "Humanisasi Pendidikan Islam" dalam Tashwirul Afkar, No 11, tahun 2000, hlm. 11. 
Al-Fikra: Jurnal Ilmiah Keislaman, Vol. 8, No. 1, Januari-Juni 2009

dan indoktrinatif. Praktek pendidikan tersebut dianggap tidak mampu menjawab tantangan zaman dan terkesan menjadikan pendidikan Islam anti realitas. Bahkan, ada anggapan bahwa pola semacam inilah yang menjadikan dan membentuk perilaku masyarakat Islam eksklusif dan gagap terhadap perubahan dan perbedaan. Karena itu, pendidikan Islam transformatif, sebuah istilah tentatif sebagai counternarrative dari PIK, perlu dimunculkan sebagai pembanding dan teman dialog untuk 'menghidupkan dan membumikan' pendidikan Islam dalam konteks hereness dan nowness. Istilah transformasi itu sendiri seringkali dimunculkan oleh Lyotard ketika membahas wacana posmodernisme sebagai lawan dari modernisme. Posmodernisme merupakan kondisi budaya yang memunculkan banyak transformasi yang mengubah rule of the game dalam bidang sains, sastra, dan seni. Di bidang pendidikan, transformasi berupa perubahan aturan main dalam hal aspek, praktek, dan institusi pendidikan yang bertanggung jawab dan mentransmisikan ilmu pengetahuan dan seni. ${ }^{3}$

Dengan menggunakan kerangka semacam ini, bagaimana pola pendidikan Islam mampu melakukan transformasi dari praktek pendidikan yang telah ada menuju kondisi yang lebih baik, mulai dari aspek konseptualisasi hingga implementasi, seperti kelembagaan, kurikulum, strategi pembelajaran, dan penyediaan SDM.

PIT mengharuskan adanya perubahan cara pandang terhadap proses pendidikan dalam faktor-faktor pendidikan. Dalam hal tujuan, pendidikan harus diorientasikan untuk mencetak individu yang berkesadaran kenabian, yang mempunyai misi liberatif terhadap berbagai persoalan sosial. Pendidikan dianggap berhasil jika mampu mencetak individu yang kritis terhadap persoalan lingkungan dengan spiritualitas Islam. Untuk menghasilkan pribadi yang semacam itu, berbagai elemen pendidikan harus ditinjau ulang. Kurikulum harus lebih terkait dengan current issues sehingga dapat memberikan bekal

3 Untuk selanjutnya, lihat tulisan Michael Peters dan Colin Lankshear, "Postmodern Counternarratives" dalam Henry Giroux, et al., Counternarratives Cultural Studies and Critical Pedagogies in Postmodern Spaces (New York \& London: Routledge, 1996), hlm. 9.
Imam Hanafi, Menuju Paradigma Pendidikan Islam Transformatif

pengetahuan dan pengalaman kepada peserta didik tentang problem riil di masyarakat.

Strategi pembelajaran harus diorientasikan untuk menghargai dan mengoptimalkan setiap potensi yang dimiliki oleh peserta didik. Karena itu, evaluasi pendidikan harus lebih berpijak pada potensi kemanusiaan peserta didik, bukan uniform yang dipaksakan oleh pendidik. Dalam hal pengelolaan, pengelola lembaga pendidikan harus mampu menggerakkan dan mengaktifkan setiap potensi yang ada di sekitarnya untuk ikut memikirkan persoalan pendidikan. Akhirnya, pendidikan tidak harus dimaknai sebagai proses yang berlangsung di ruang kelas saja, namun juga terjadi di luar kelas. Karena itu, upaya mensinergikan antara unit keluarga, sekolah, dan masyarakat perlu dilakukan.

\section{Pendidikan Tranformatif dan Pedagogi Kritis}

Istilah pedagogi kritis (critical pedagogy) muncul seiring dengan maraknya kajian tentang pendidikan pembebasan, pendidikan untuk kaum tertindas, yang dilontarkan oleh Paulo Freire asal Brasil.4 Dalam buku Conternarratives Colin Lankshear, Michael Peters, dan Michele Knobel5 banyak mengulas pemikiran Freire yang mengusung tema pendidikan pembebasan. Menurut mereka, pendidikan kritis pada dasarnya bermula dari gagasan Freire. Menurut mereka ada beberapa ciri pendidikan kritis. Pertama, pendidikan pada dasarnya merupakan bentuk kritik sosial dan kultural, bahwa semua pengetahuan pada dasarnya dimediasi oleh relasi bahasa yang dibentuk secara sosial dan historis.

Salah satu tujuan pendidikan adalah rekonstruksi sosial. Lembaga pendidikan merupakan media yang diharapkan mampu memperbaiki dan mengkritisi berbagai persoalan yang muncul di

${ }^{4}$ Lihat karya Paulo Freire, Pedagogy of the Oppressed (New York: Seabury, 1970) dan Education for Critical Consciousness (New York: Seabury, 1973).

5 Misalnya Lihat Henry Giroux, Colin Lankshear, Peter McLaren, dan Michael Peters, Counternarratives: Cultural Studies and Critical Pedagogies in Postmodern Spaces, (New York \& London: Routledge, 1996), hlm. 125-126. 
A1-Fikra: Jurnal Ilmiah Keislaman, Vol. 8, No. 1, Januari-Juni 2009

masyarakat yang diakibatkan oleh faktor ekonomi, politik, dan budaya Karena itu, berbagai persoalan yang berkembang dalam realitas empirik tersebut dibawa ke ruang kelas untuk dikritisi dan dicarikan jalan keluar melalui proses kodifikasi konteks. Hasil pembahasan in kemudian ditawarkan dan dilaksanakan sebagai alternatif pemecahan. Proses ini tidak akan berjalan secara maksimal jika tidak ada kesadaran kritis dari praktisi pendidikan terutama pendidik dan peserta didik.

Kedua, eksistensi seseorang sangat terkait dengan masyarakat yang lebih luas baik dalam lingkup keluarga, masyarakat, ataupun lembaga pendidikan. Artinya kesadaran seseorang pada dasarnya merupakan cermin kesadaran kolektif yang dibentuk melalui mediasi keluarga, masyarakat, sekolah dan sebagainya.6 Sebab, ia belajar dari orang di sekitarnya. Dalam konteks pendidikan kritis, masalahnya terletak pada kondisi seseorang ketika hidup dalam konteks masyarakat yang tidak memungkinkan dia mengembangkan potensi secara optimal, bahkan mandeg karena faktor struktural atau kultural.7 Sebagai contoh, dia hidup dalam struktur politik yang represif yang tidak memungkinkannya leluasa mengeluarkan hak berpendapat untuk mengungkapkan keinginannya. Dia bahkan mungkin tidak menyadar bahwa dia sedang mempunyai permasalahan yang disebabkan oleh persoalan ekonomi atau politik yang 'dikondisikan' oleh pihak lain. Untuk itu, proses pendidikan adalah upaya untuk 'menyadarkan' seseorang tentang kondisi dia yang sebenarnya. Dalam paradigma pendidikan kritis, dia dibawa dari kesadaran naïf8 ke kesadaran kritis.9

${ }^{6}$ Joe L. Kincheloe, and McLaren, Peter, "Rethinking Critical Theory and Qualitative Research," in Norman K. Denzin and Yuonna S. Lincoln (Eds.) Handbook of Qualitative Research (Second Edition). (London: Sage Publication, Inc., 2000), hlm. 139-140.

Colin Lankshear, Michael Peters and Michele Knoebel, "Critical Pedagogy and Cyberspace" in Henry Giroux, Colin Lankshear, Peter McLaren, dan Michael Peters, Counternarratives, hlm. 150.

${ }^{8}$ Sebagai ilustrasi, kesadaran naif adalah ketika seseorang mengetahui bahwa dia sebenarnya 'bermasalah', namun tidak kuasa mengatasi karena dikondisikan secara eksternal seperti ekonomi, politik, hokum, dan budaya.
Imam Hanafi, Menuju Paradigma Pendidikan Islam Transformatif

Ketiga, fakta sosial tidak pernah dapat dipisahkan dengan ranah nilai.10 Ini berarti bahwa berbagai aktifitas yang terjadi dalam realitasempirik merupakan perwujudan atau cermin nilai dari sang pelaku. Karena itu, menurut paradigma ini, ada hubungan yang erat antara aktifitas dan tindakan dengan nilai, antara konsep dengan obyek dan antara signifier dengan signified. Hubungan tersebut tidak selalu tetap (fixed) dan seringkali dimediasi oleh lingkaran produksi, konsumsi, dan relasi sosial. Untuk itu, pembacaan kritis terhadap sebuah fakta sosial harus selalu dilakukan. Sebagai contoh, terma pembangunan dapat dimaknai secara beragam oleh berbagai pihak hanya karena perbedaan pemahaman dan nilai yang dibangun selama ini. Bagi pemerintah, pembangunan merupakan terma yang digunakan sebagai proses mensejahterakan masyarakat. Karena itu, jika ada pembangunan jalan tol, maka berarti ada upaya mensejahterakan masyarakat. Namun, bagi masyarakat kata pembangunan dapat berarti sebaliknya, misalnya analog dengan penggusuran, relokasi atau ganti rugi. Anggapan ini muncul karena dalam realitasnya seringkal pembangunan dilakukan tidak didasarkan pada kebutuhan riil di masyarakat, namun didasarkan pada kemauan dari penguasa (topdown). Untuk mengatasi hal tersebut, perlu ada dialog terbuka antar berbagai pihak sehingga ada persamaan persepsi antara pihak pemerintah dan masyarakat.

Keempat, bahasa merupakan pusat bagi formasi subyektifitas. Dalam perspektif ini kepentingan, kebutuhan, dan kecenderungan seseorang atau lembaga dimunculkan melalui media bahasa.11 Di sisi lain, bahasa pada dasarnya merupakan bentuk aksentuasi pemikiran seseorang yang kemudian disepakati bersama oleh masyarakat. Karena itu, sangat banyak dijumpai ragam bahasa yang digunakan masyarakat.

9 Sementara itu, kesadaran kritis terjadi ketika seseorang menyadari permasalahan yang dihadapi [dan problem masyarakat sekitar] dan aktif dalam pencarian alternative pemecahan.

10 Peter McLaren, "Liberatory Politics and Higher Education: A Freirean Perspective" in Henry Giroux, Colin Lankshear, Peter McLaren, dan Michael Peters, Counternarratives, hlm. 125.

${ }^{11} \mathrm{Ibid}$. 
Al-Fikra: Jurnal Ilmiah Keislaman, Vol. 8, No. 1, Januari-Juni 2009

Kata yang dimunculkan oleh sebuah komunitas belum tentu dimaknai secara persis sama oleh komunitas lain. Karena itu, seringkali dijumpa di masyarakat ada permasalahan yang muncul diakibatkan oleh perbedaan bahasa dan kultur.

Kelima, munculnya perbedaan status di kalangan anggota masyarakat baik secara ekonomi maupun sosial disebabkan oleh pemberian previlise secara tidak adil oleh pihak lain, seperti pihak birokrat, politisi, dan pemilik modal, karena kepentingan tertentu. Masalahnya, banyak anggota masyarakat yang menganggap perbedaan itu terjadi begitu saja, alami, dan niscaya. Dalam perspektif kritis, munculnya perbedaan tersebut sangat mungkin disebabkan oleh perlakuan yang tidak adil karena ada banyak kepentingan. Untuk itu, masyarakat perlu disadarkan tentang kondisi ini. Ini tidak berarti bahwa semua anggota masyarakat harus sama, namun ketika cara mendapatkan kekayaan, status social, atau jabatan itu dilakukan secara wajar dan prosedural, tentu hal ini akan diterima, sebab bagaimanapun kemampuan antara satu orang dengan yang lain berbeda.

Akhirnya, dalam perspektif kritis munculnya berbagai permasalahan di masyarakat tidak dapat dilihat hanya dari satu sisi saja, namun perlu mengaitkan dengan aspek lain.12 Sebagai contoh, persoalan ekonomi tidak cukup hanya dilihat dari perspektif ekonomi, namun perlu dikaitkan dengan politik, budaya, bahkan pemahaman terhadap ajaran agama. Memandang permasalahan dari satu segi saja sama halnya dengan menyederhanakan masalah. Proses pendidikan harus mampu melihat persoalan yang muncul di masyarakat dari banyak perspektif. Sebagai contoh, banyaknya tenaga pendidik [guru] yang "ngobyek" di luar profesi sebagai guru tidak dapat dilihat dari aspek profesionalisme dan etos kerja guru saja, namun perlu dikaitkan dengan masalah kebijakan pemerintah yang belum menghargai profesi guru, atau rendahnya penghargaan masyarakat terhadap profesi ini.

Keenam karakter pendidikan kritis di atas pada dasarnya merupakan proses transformasi peserta didik secara individual maupun sosial. Artinya, dalam perspektif pendidikan kritis munculnya

${ }^{12}$ Peter McLaren, "Liberatory Politics”, hlm. 126.
Imam Hanafi, Menuju Paradigma Pendidikan Islam Transformatif

berbagai permasalahan yang menimpa seseorang disebabkan oleh dua faktor, yaitu internal dan eksternal. Secara internal, dia belum mencapai kesadaran kritis yang mampu menyelesaikan persoalan yang ada dalam diri dan juga masyarakat sekitarnya. Hal ini merupakan cermin bahwa proses pendidikan belum sepenuhnya mengoptimalkan potensi yang dimiliki peserta didik. Untuk itu, praktik pendidikan harus diorientasikan untuk mengaktualisasikan semua potensi yang dimiliki peserta didik tanpa ada kepentingan tertentu dari pihak penguasa atau pengelola lembaga pendidikan. Di sisi lain, secara eksternal, munculnya problem yang menimpa seseorang karena faktor dari luar, misalnya ketidakadilan sosial, kepentingan politik, kepentingan ekonomi pemilik modal, atau kultur yang kurang menguntungkan. Untuk itu, dia harus disadarkan melalui proses pendidikan di mana ada proses refleksi dan aksi. Refleksi dilakukan untuk membahas dan mencari alternatif pemecahan terhadap problem realitas di ruang kelas, sementara aksi merupakan tindak lanjut dari proses refleksi tersebut ke luar kelas.

Dikaitkan dengan paradigma dalam ilmu-ilmu sosial, pendidikan kritis pada dasarnya satu alur dengan paradigma transformatif,13 bukan positivistik atau interpretif. Paradigma postivistik mencakup psitivisme, neopositivisme, positivisme metodologis, dan positivisme logis, sementara paradigma interpretif mencakup interaksionisme simbolis, fenomenologi, etnometodologi, hermeneutika, psikoanalisa, etnologi, etnografi, dan sosiolinguistik, dan paradigma transformatif mencakup sosiologi kritis, conflict school of thought, Marxisme, dan feminisme.14 Ketiga paradigma tersebut mempunyai perbedaan dalam memandang realitas, manusia, ilmu pengetahuan, dan tujuan penelitian. Dalam paradigma transformatif realitas merupakan sesuatu yang kompleks, apa yang tampak (appearance) sebenarnya belum

13 Elliot W. Eisner, "Curriculum Ideologies" in Philip W. Jackson (ed.), Handbook of Research on Curriculum (New York: Simon and Schuster Macmillan, 1996), hlm. 314-316.

14 Sotirios Sarantakos, Social Research, 2nd edition (Australia: Macmillan Education Australia Pty Ltd., 1998), hlm. 33. 
A1-Fikra: Jurnal Ilmiah Keislaman, Vol. 8, No. 1, Januari-Juni 2009

menggambarkan realitas sesungguhnya, sebab realitas diciptakan oleh orang, bukan dikondisikan oleh alam.15

Di balik yang tampak terdapat banyak ketegangan karena ada banyak kepentingan dari pelaku. Pandangan ini berbeda dengan paradigma positivistik yang beranggapan bahwa ralitas bersifat obyektif, dipersepsi melalui indera, dipersepsi secara seragam oleh semua orang, dan diatur berdasarkan hukum eksternal.16 Sementara itu, bagi paradigma interpretif, realitas bersifat subyektif, berada dalam pikiran orang dan ditafsirkan secara beragam oleh setiap orang.

Tentang manusia, paradigma transformatif berpendapat bahwa ia adalah pencipta bagi nasibnya sendiri, ia seringkali ditindas, dialienasi, dieksploitasi, dibatasi, dikondisikan, dan dihambat realisasi potensinya. Hal ini berbeda dengan paradigma positivistik yang berpandangan bahwa manusia adalah individu rasional yang mentaati hukum eksternal dan tanpa free will, sementara paradigma interpretif menganggap manusia sebagai pencipta dunianya sendiri, tidak dibatasi oleh hukum eksternal, dan menciptakan sistem makna.

Sementara itu, tentang ilmu pengetahuan dan tujuan penelitian, ketiga paradigma di atas mempunyai arah yang jauh berbeda. Bagi paradigma positivistik, ilmu pengetahuan didasarkan pada aturan dan prosedur yang ketat, bersifat deduktif, bergantung pada kesan indra, dan bebas nilai. Dengan pandangan ini, tujuan penelitian positivistik adalah untuk menjelaskan kehidupan sosial, memprediksi sejumlah peristiwa, dan menemukan hukum-hukum kehidupan sosial. Sementara itu, bagi paradigma interpretif, ilmu pengetahuan didasarkan pada common sense, bersifat induktif, tergantung pada penafsiran, dan tidak bebas nilai. Bagi paradigma ini tujuan penelitian adalah untuk menafsirkan dan memahami kehidupan sosial, serta menemukan makna yang dimiliki oleh orang lain. Akhirnya, bagi paradigma transformatif, ilmu pengetahuan adalah kondisi yang membentuk kehidupan, namun kondisi ini dapat diubah, bersifat membebaskan dan memberdayakan, bergantung pada kesan indra dan

\footnotetext{
15 Ibid,hlm. 36.
}

${ }^{16}$ Ibid.
Imam Hanafi, Menuju Paradigma Pendidikan Islam Transformatif

nilai, dan tidak bebas nilai. Dalam perspektif ini, tujuan penelitian adalah untuk menjelaskan, menafsirkan, dan mengurai kehidupan sosial, mengungkap mitos dan ilusi, dan untuk membebaskan dan memberdayakan masyarakat.

\section{Kearah Pendidikan Islam Transformatif}

Secara konseptual pendidikan Islam sebenarnya sudah cukup kaya dan sempurna sebab ingin membentuk pribadi muslim sempurna dan mendapatkan kebahagiaan hidup di dunia dan akhirat, meskipun lebih cenderung normatif.17 Sebab, dalam realitasnya, praktik pendidikan Islam cenderung 'idealis' dan kurang bersentuhan dengan problem realitas-empirik. Hal ini antara lain disebabkan oleh adanya anggapan bahwa segala aktifitas hidup umat Islam, termasuk pendidikan, harus didasarkan pada wahyu yang given dari Tuhan dalam pengertian harfiah sehingga cenderung kurang melihat aspek realitas yang empirik.

Karena itu, wajar jika formulasi tentang konsep pendidikan Islam relatif idealis dan kurang 'membumi', kurang bersentuhan dengan problem realitas. Padahal, sosok Nabi sendiri yang dijadikan sebagai model bagi pendidikan Islam jelas-jelas terlibat langsung dalam penyelesaian problem di masyarakat.

Karena itu, jika paradigma pendidikan kritis diterima dengan beberapa penyesuaian, maka yang perlu dipikirkan adalah tindak lanjut secara praktis, mulai dari perumusan orientasi pendidikan Islam, pembaharuan kurikulum, penyiapan sumber daya manusia, diversifikasi strategi pembelajaran, perubahan model evaluasi, evaluasi kebijakan, dan perubahan manajemen di lembaga pendidikan mulai dari tingkat dasar sampai pendidikan tinggi. Berbagai komponen ini

17 Baca kajian Azyumardi Azra tentang literature pendidikan Islam yang ada di Indonesia. Azyumardi Azra, Pendidikan Islam Tradisi dan Modernisasi Menuju Milenium Baru (Jakarta: Logos, 1999), 90-93. Bandingkan dengan Muqowim, "Dinamika Kajian Islam "Mazhab Sapen" Pemetaan atas Karya Disertasi di Program Pascasarjana IAIN Sunan Kalijaga Yogyakarta" dalam Profetika Jurnal Studi Islam, Vol. 6, No. 1, Januari 2004: hlm. 53-57. 
A1-Fikra: Jurnal Ilmiah Keislaman, Vol. 8, No. 1, Januari-Juni 2009

perlu dikaji secara terpadu, simultan, dan komprehensif. Hal ini tidak hanya menjadi tanggung jawab praktisi pendidikan Islam saja, namun semua stakeholder pendidikan harus dilibatkan, mulai dari tenaga kependidikan di lembaga pendidikan formal, peserta didik, alumni, pengguna alumni, orang tua, tokoh masyarakat, kalangan LSM, akademisi, dan pejabat pemerintah terkait. Sebab, proses pendidikan tidak dapat berjalan secara linear dan monolitik, namun secara sirkular dan melibatkan banyak komponen.

Dalam hal orientasi, pendidikan Islam seharusnya tidak sekedar membentuk kesalehan individual semata, atau kesadaran mistik dalam perspektif Iqbal, namun harus membentuk kesalehan sosial juga. Sebagaimana disinyalir Iqbal pada awal abad ke-20 dan hingga sekarang masih terasa, umat Islam di dunia Timur cenderung mengedepankan kesadaran mistik dan kesalehan individual yang diibaratkan dengan larut dengan tasbih, yang penting selamat di akhirat, sementara problem sekitar tidak begitu dipikirkan.18 Untuk itu, orientasi pendidikan harus diarahkan untuk membentuk individu muslim yang mempunyai kesadaran kenabian dengan karakter emansipatif, liberatif dan transendental yang mampu membaca problem empirik di sekitarnya sehingga ia mampu terlibat dalam penyelesaian problem. Tetapi, di sisi lain, dia juga mampu menyelesaikan setiap problem yang menimpanya.

Perubahan orientasi perlu segera diimbangi dengan perubahan kurikulum yang akan dibekalkan kepada setiap peserta didik. Sebagaimana dirumuskan oleh al-Attas, bahwa kurikulum pendidikan Islam dikonstruk berdasarkan ajaran al-Qur'an dan al-Sunnah, namun harus didialogkan dengan problem realitas sehingga muatannya dinamis sesuai dengan konteks waktu dan tempat.19 Dalam pengertian ini, sebenarnya perubahan kurikulum dapat dilakukan kapan saja, tanpa menunggu jangka waktu tertentu. Sebab, ketika

18 K.G. Saiyidain, "Progressive Trends in Iqbal's Thought" in Eminent Scholars, Iqbal as A Thinker (Lahore: Sh. Muhammad Ashraf, 1991), hlm. 56.

19 Wan Mohd Nor Wan Daud, Filsafat dan Praktik Pendidikan Islam Syed M. Naquib al-Attas, terj. Hamid Fahmy dkk. (Bandung: Mizan, 2003), hlm. 266.
Imam Hanafi, Menuju Paradigma Pendidikan Islam Transformatif

problem dan tantangan yang dihadapi oleh masyarakat berbeda dan berubah, maka harus diikuti oleh perubahan kurikulum jika tidak ingin tertinggal dengan perubahan. Kurikulum dalam perspektif pendidikan kritis harus selalu mendialogkan teks dan konteks, antara normatif dan historis. Karena itu, akan selalu ada upaya kontekstualisasi teks sehingga mampu menjawab problem bumi. Dalam pandangan Freire, akan selalu ada proses kodifikasi konteks dan dekodifikasi. Kodifikasi konteks berarti mendialogkan, mendiskusikan dan mencari alternatif pemecahan terhadap problem yang berkembang di masyarakat ke dalam ruang ruang kelas.20 Hasil rumusan alternatif ini kemudian dibawa ke masyarakat sebagai sebuah tawaran pemecahan. Dengan demikian, ada proses refleksi di ruang kelas dan proses aksi di luar kelas secara terus-menerus. Ketika problem yang ada di masyarakat berkembang, maka perlu ada kodifikasi kembali dan begitu seterusnya.

Hanya saja, sebagaimana disinyalir oleh Rahman, umat Islam harus melihat kandungan teks al-Qur'an dan al-Sunnah secara hermeneutis, dalam arti bahwa perlu ada upaya pencarian tentang ide moral yang terkandung dalam teks al-Qur'an. Ini hanya dapat dilakukan jika umat Islam melakukan kritik sejarah terhadap diturunkannya kitab tersebut. Untuk itu, Rahman menawarkan double movement methodology untuk dapat menangkap ide moral alQur'an.21 Dalam pandangannya, sejak dulu sampai akhir zaman, teks al-Qur'an tetap, namun formulasi untuk pembumiannya dinamis tergantung problem yang berkembang di masyarakat.

Berdasarkan pemikiran tersebut, kurikulum dalam pendidikan Islam kritis, apa pun nama pengetahuan yang akan diajarkan, mengharuskan ada perpaduan secara dinamis antara teks dan konteks. Untuk itu, paradigma contextual teaching learning perlu diterapkan, artinya setiap materi yang disampaikan oleh pendidik harus bermakna bagi peserta didik. Apa yang dipelajari di dalam kelas harus selalu dikaitkan dengan problem dan konteks keseharian yang dihadapi peserta didik. Sebagai contoh, ketika berbicara tentang kerusakan

20 Peter McLaren, "Liberatory Politics and Critical Pedagogy", hlm. 142.

${ }^{21}$ Fazlur Rahman, Islam and Modernity, hlm. 15 
Al-Fikra: Jurnal Ilmiah Keislaman, Vol. 8, No. 1, Januari-Juni 2009

lingkungan, harus ada dialog antara teks al-Qur'an dengan problem lingkungan yang ada di sekitar sekolah yang bersangkutan. Jika sekolah itu bertempat di Kalimantan, maka perlu dikaitkan dengan kasus illegal logging atau pembakaran hutan. Untuk di Riau misalnya, kasus-kasus dan isu illegal logging atau pembakaran hutan ini menjadi relevan untuk diangkat. Karena itu, dalam kurikulum ini harus lebih banyak memasukkan problem dan kearifan lokal.

Perubahan orientasi dan kurikulum tersebut, juga harus diimbangi dan dibarengi dengan penyiapan sumber daya manusia yang mampu mengimplementasikan orientasi dan kurikulum itu dalam konteks praxis. Dalam sebuah adagium Arab dikenal al-mudarris ahammu min al-maddah wa al-tariqah. Sebaik apa pun materi dan strategi pembelajaran, jika tidak dipahami oleh pendidik, maka tidak akan berjalan secara maksimal. Untuk itu, perubahan mindset di kalangan praktisi pendidikan perlu dilakukan segera. Yang perlu dicermati bahwa merubah kultur berpikir tidak semudah merubah struktur. Jika perubahan struktur dapat dilakukan dalam hitungan hari bahkan jam, maka perubahan kultur [berpikir] memerlukan waktu cukup lama, tidak hanya tahunan bahkan generasi. Tidak mengherankan jika dalam kenyataan telah terjadi perubahan struktur [pemerintahan dan pengelola lembaga pendidikan], namun belum ada perubahan kultur. Sebab, orang yang menjalankan struktur baru tersebut masih sama dengan kultur lama.

Dalam pendidikan Islam Transformatif, sumber daya manusia pertama yang harus dibenahi adalah pendidik. Ini tidak berarti yang lain tidak perlu dibenahi. Namun, para pendidiklah yang menjadi ujung tombak (avant garde) terjadinya perubahan. Sebab, mereka yang selalu terlibat langsung dengan peserta didik dan yang mengimplementasikan kurikulum. Ini berarti, berhasil tidaknya sebuah rumusan dan konsep kurikulum dalam konteks praktis sangat ditentukan oleh faktor pendidik. Semakin berkualitas pendidik, semakin berhasil dalam membawa perubahan.

Dikaitkan dengan implementasi Kurikulum 2004 yang terkenal dengan kurikulum berbasis kompetensi (KBK), sosok pendidik sangat diharapkan untuk keberhasilan kurikulum baru tersebut. Sebab, dalam 120
Imam Hanafi, Menuju Paradigma Pendidikan Islam Transformatif

pengelolaan kurikulum yang berujung pada penjabaran silabus dan materi pembelajaran dari rumusan kompetensi minimal yang ditetapkan oleh pemerintah pusat lebih diserahkan kepada pihak sekolah/madrasah, khususnya pendidik. Dalam hal ini mereka dapat bekerjasama dengan berbagai pihak terkait seperti kepala sekolah, akademisi di perguruan tinggi dan tokoh masyarakat, namun yang menjadi inisator adalah pendidik.

Posisi pendidik semakin penting mengingat penjabaran materi sangat diserahkan ke tiap wilayah, bahkan lembaga pendidikan, untuk mengembangkannya tergantung kebutuhan. Hal ini didasari oleh prinsip pengelolaan KBK 'kesatuan dalam kebijakan dan keragaman dalam pelaksanaan.' Karena itu, sangat dimungkingkan adanya perbedaan implementasi dan pengembangan antara satu wilayah dengan wilayah lain. Bahkan, dalam satu wilayah pun sangat dimungkinkan adanya keragaman implementasi antara satu lembaga pendidikan dengan lembaga pendidikan lain. Untuk itu, diperlukan pendidik yang mampu menerjemahkan dan menjabarkan kompetensi dasar sesuai dengan kondisi wilayah dan sekolah.

Pendidik bukan lagi menjadi satu-satunya sumber belajar, sebab apa pun dapat dijadikan sebagai sumber belajar selama mendukung pencapaian hasil belajar. Sumber belajar yang dirancang secara khusus, seperti miniatur ka'bah, masjid, atau piramida, ataupun sumber belajar yang tinggal memanfaatkan seperti praktisi perbankan, politisi, tokoh masdyarakat, sungai, internet, radio, dan surat kabar, mempunyai fungsi yang sama dalam mengoptimalkan pencapaian hasil belajar peserta didik. Hal ini menuntut pendidik untuk semakin aktif dan kreatif dalam proses pembelajaran jika tidak ingin ketinggalan dengan peserta didiknya yang dapat belajar dari banyak sumber. Berdasarkan pemikiran tersebut, dalam konteks pendidikan kritis diperlukan tenaga kependidikan yang mempunyai pengetahuan dinamis tentang strategi pembelajaran.

Proses pembelajaran harus mampu mengoptimalkan segenap potensi peserta didik dengan cara melibatkan mereka secara fisik dan mental dalam setiap pembelajaran. Untuk itu, strategi pembelajaran yang diterapkan pendidik harus mempertimbangkan setiap 
A1-Fikra: Jurnal Ilmiah Keislaman, Vol. 8, No. 1, Januari-Juni 2009

kecenderungan tipe belajar setiap peserta didik, apakah tipe somatik, auditif, visual atau intelektual. Peserta didik yang mempunya kecenderungan somatik tidak akan maksimal dalam belajarnya jika pendidik menggunakan strategi belajar dengan ceramah, sebab metode ini hanya cocok bagi peserta didik dengan tipe belajar auditif. Tipe somatik hanya cocok jika pendidik menggunakan strategi yang membuat peserta didik terlibat secara fisik (learning by doing). 22

Bergitu juga, peserta didik dengan tipe belajar visual akan tepat dan maksimal jika pendidik menggunakan strategi pembelajaran dengan contoh-contoh visual atau gambar, sementara peserta didik dengan tipe belajar intelektual akan tepat jika menggunakan strategi pembelajaran dengan penalaran.

Di sisi lain, seorang pendidikan harus kritis mencermati persoalan kependidikan, mulai dari penyimpangan praktik pendidikan di lapangan, kebijakan yang tedak tepat sampai persoalan yang menimpa dirinya sebagai seorang pendidik. Hal ini dilakukan agar pendidik [baca : guru] tidak hanya menjadi sosok manusia yang pasrah dan pasif karena dikenal sebagai pahlawan tanpa tanda jasa atau sosok Umar Bakri yang lugu dan sederhana. Dalam perspektif kritis, kesederhanaan pendidik tentu masih sangat relevan tetapi tanpa mengabaikan peran dia yang harus kreatif dan kritis dalam menyelesaikan persoalan pendidikan. Masalah pendidikan tidak hanya diserahkan kepada para akademisi di perguruan tinggi atau pengambil keibjakan saja, namun dia juga harus berperan aktif dalam menyelesaikannya dengan kemampuan yang dimiliki.

Berdasarkan elaborasi singkat tersebut tampak bahwa diversifikasi strategi pembelajaran oleh pendidik mutlak diperlukan mengingat dalam satu kelas terdapat banyak peserta didik yang mempunyai banyak kecenderungan tipe belajar. Untuk itu, tidak ada strategi belajar yang paling tepat untuk setiap waktu dan tempat. Hal ini sangat dipengaruhi oleh tujuan pembelajaran, kondisi peserta didik, waktu, fasilitas, dan pendidik. Yang jelas, untuk konteks pendidikan

22 Dave Meier, The Acclerated Learning Handbook (USA: McGraw-Hill Co., 2000), hlm. 41-52
Imam Hanafi, Menuju Paradigma Pendidikan Islam Transformatif

kritis, strategi pembelajaran diabdikan untuk mengoptimalkan potensi peserta didik, bukan untuk memenuhi harapan pendidik dan menghabiskan materi. Pendidik dituntut mengajar peserta didik untuk selalu dalam proses pencarian ilmu yang kritis dan dinamis, agar dia tidak terjebak pada context of justification, namun context of discovery.23

Perubahan lain yang perlu dilakukan jika pendidikan kritis diterapkan adalah konsep evaluasi. Evaluasi harus dimaknai sebagai upaya untuk mengetahui sejauhmana proses pembelajaran yang dilakukan di sekolah mampu mengoptimalkan potensi yang dimiliki oleh setiap peserta didik. Karena potensi yang dimiliki peserta didik tidak tunggal, maka sasaran evaluasi juga tidak boleh tunggal. Evaluasi harus bertolak dari keragaman potensi yang dimiliki setiap peserta didik. Karena itu, evaluasi yang selama ini lebih melihat pada beberapa mata pelajaran tertentu, seperti mata pelajaran yang di-Ebtanas-kan, dalam perspektif pendidikan kritis adalah tidak tepat. Sebab, yang dihargai hanya beberapa mata pelajaran saja, belum semua mata pelajaran. Ini sama saja hanya menghargai salah satu potensi yang dimiliki peserta didik.

Idealnya, setiap potensi dan kecenderungan peserta didik dihargai. Menurut Gardner, peserta didik paling tidak mempunyai delapan kecenderungan, yang kemudian dia jelaskan menjadi ragam kecerdasan (multiple intelligence), yaitu cerdas angka, kata, ruang, irama, fisik, interpersonal, intrapersonal, dan alam.24 Dalam perspektif ini, jika selama ini prestasi anak hanya dilihat dari mata pelajaran matematika saja, sebenarnya ini baru melihat satu jenis kecerdasan, yaitu cerdas angka, padahal tidak semua peserta didik mempunyai kecenderungan ini. Untuk itu, dalam perspektif

${ }^{23}$ M. Amin Abdullah, "Preliminary Remarks on the Philosophy of Islamic Relious Sciences" dalam Al-Jami'ah Journal of Islamic Studies, No. 61 tahun 1998, hlm. 6

${ }^{24}$ Lihat karya-karya bukunya Gordon Dryden and Jeannette Vos, The Learning Revolution To Change the Way the World Learns (USA: The Learning Web, 1999), 443 dan 489; Thomas Armstrong, Multiple Intelligence in the Classroom (ASCD, 1994). 
A1-Fikra: Jurnal Ilmiah Keislaman, Vol. 8, No. 1, Januari-Juni 2009

pendidikan kritis, setiap jenis kecerdasan ini harus diapresiasi dan dioptimalkan, sehingga setiap kecenderungan anak diperhatikan. Dalam jangka panjang tidak ada anak yang merasa minder hanya karena ia tidak cerdas angka, padahal ia cerdas kata atau cerdas fisik Selain itu, tidak ada peserta didik yang merasa 'di atas angin' dibandingkan teman-teman yang lain hanya karena dia mempunyai kecerdasan angka.

Berbagai agenda perubahan dalam praktek pendidikan berperspektif kritis tersebut tidak akan berjalan maksimal tanpa adanya dukungan politik dari pihak pemerintah. Untuk konteks keindonesiaan, perubahan manajemen pemerintahan dari sentralisasi ke desentralisasi mengharuskan pemerintah [pusat] mengkondisikan berbagai aturan yang memungkinkan berjalannya konsep otonomi terutama dalam bidang pendidikan. Dalam manajemen baru ini, pemerintah pusat tidak lagi menjadi pemegang otoritas pembuatan kebijakan, apalagi sampai pembuatan juklak dan juknis. Pemerintah hanya membuat rambu-rambu yang bersifat global. Untuk itu, perlu ada evaluasi kebijakan dalam bidang pendidikan, mana kebijakan yang memberikan ruang bagi praktisi pendidikan untuk kreatif dan mana kebijakan yang menghambat dan mengekang.

Dalam konteks otonomi, kreatifitas masyarakat, khususnya pengelola lembaga pendidikan sangat diperlukan. Sebab, merekalah yang paling tahu kebutuhan dirinya. Untuk itu, pengembangan lembaga pendidikan sangat ditentukan oleh pengelola lembaga pendidikan, khususnya kepala sekolah. Munculnya konsep manajemen berbasis sekolah dalam perspektif TQM (total quality management) merupakan wujud adanya pemberian keleluasaan pihak sekolah untuk merumuskan arah kebijakannya sendiri sesuai dengan kebutuhan riil, bukan ditentukan dari atas. Untuk memenuhi kebutuhan tersebut, dia harus mampu memanaj potensi yang ada di sekitarnya, untuk itu harus mampu mensinergikan peran dan potensi para stakeholder pendidikan.

\section{Kesimpulan}

Imam Hanafi, Menuju Paradigma Pendidikan Islam Transformatif

Pendidikan merupakan unsur elementer yang tidak dapat dilepaskan dari aspek teologis. Komitmen Islam secara teologis terhadap pendidikan dapat dilacak pada al-Qur'an surat al-Alaq (96):114. Ungkapan "pengajaran" dan "pembacaan" yang ada pada ayat-ayat itu mengimplikasikan, perintah mengajar dan membaca (meneliti dan sebagainya) tidak terbatas pada penyampaian risalah Allah yang harus dilakukan Rasul, tetapi juga bersifat universal, menukik pada tugas untuk menyebarkan kebenaran oleh semua orang yang membaca dan memahami ajaran al-Qur'an. Nilai-nilai dan komitmen Islam itu akan makin tampak bila dikaitkan dengan Hadis A'isyah tentang permulaan turunnya wahyu, di mana Tuhan menyuruh "membaca" kepada Muhammad. Pertama kali Nabi menolak karena dia tidak bisa membaca. Namun, Tuhan menjelaskan, "membaca" adalah kewajiban manusia; mencari dan mengamalkan pengetahuan adalah sifat intrinsik yang harus ada pada manusia. Ini juga menggambarkan proses penyampaian pengetahuan dalam Islam, yaitu sifatnya yang sangat menekankan pada penciptaan suasana dialogis dan aktif. Pada sisi ini, batasan pendidikan Islam prinsipnya merupakan proses pengenalan dan pengakuan yang ditanamkan secara bertahap dan berkesinambungan dalam diri manusia mengenai obyek-obyek yang benar sehingga hal itu akan membimbing manusia ke arah pengenalan dan pengakuan terhadap eksistensi Tuhan dalam kehidupan. Selanjutnya, dengan pengetahuan itu, manusia diarahkan untuk mengembangkan kehidupan lebih baik. Berdasarkan paparan yang telah penulis uraikan diatas, semakin mempertegas bahwa konsep allama ma lam ya'lam (Tuhan mengajarkan segala hal yang tidak diketahui manusia) mengandung pengertian, Allah selalu mengajarkan suatu pengetahuan baru setiap saat kepada manusia. Sehingga manusia dituntut untuk belajar tentang apa saja sepanjang hidupnya, dan hendaknya selalu berdialog secara tranformatif dengan perkembangan zaman. Manusia tidak boleh berhenti pada pengetahuan yang dimilikinya, tetapi mesti selalu mencari sesuatu "yang baru" diluar dirinya. Lebih-lebih seorang guru, sebagai bagian penting dalam proses pendidikan, menjadi lebih dituntut untuk melakukan proses transformasi ini. Wallabu a'lam bi al-Shoawab. 
A1-Fikra: Jurnal Ilmiah Keislaman, Vol. 8, No. 1, Januari-Juni 2009

\section{Bibliografi}

Abdullah, M. Amin, "Preliminary Remarks on the Philosophy of Islamic Relious Sciences" dalam Al-Jami'ah Journal of Islamic Studies, No. 61 tahun 1998.

Armstrong, Thomas, Multiple Intelligence in the Classroom (ASCD, 1994).

Azra, Azyumardi, Pendidikan Islam Tradisi dan Modernisasi Menuju Milenium Baru (Jakarta: Logos, 1999).

Daud, Wan Mohd Nor Wan, Filsafat dan Praktik Pendidikan Islam Syed M. Naquib al-Attas, terj. Hamid Fahmy dkk. (Bandung: Mizan, 2003).

Dryden, Gordon and Jeannette Vos, The Learning Revolution To Change the $W$ ay the World Learns (USA: The Learning Web, 1999).

Eisner, Elliot W., "Curriculum Ideologies" in Philip W. Jackson (ed.), Handbook of Research on Curriculum (New York: Simon and Schuster Macmillan, 1996).

Freire, Paulo, Education for Critical Consciousness (New York: Seabury, 1973).

Pedagogy of the Oppressed (New York: Seabury, 1970).

Giroux, Henry, Colin Lankshear, Peter McLaren, dan Michael Peters, Counternarratives: Cultural Studies and Critical Pedagogies in Postmodern Spaces, (New York \& London: Routledge, 1996).

Kincheloe, Joe L. and McLaren, Peter, "Rethinking Critical Theory and Qualitative Research," in Norman K. Denzin and Yuonna S. Lincoln (Eds.) Handbook of Qualitative Research (Second Edition). (London: Sage Publication, Inc., 2000).

Mastuhu, "Pendidikan Islam di Indonesia Masih Berkutat pada Nalar Islami Klasik" dalam Tashfirul Afkear Jurnal Refleksi Pemikiran Keagamaan dan Kebudayaan, No. 11 Tahun 2001
Imam Hanafi, Menuju Paradigma Pendidikan Islam Transformatif

Meier, Dave, The Accelerated Learning Handbook (USA: McGraw-Hill Co., 2000)

Muqawim, "Mencari Format Baru Pendidikan Islam dalam Masyarakat Plural" dalam Jurnal Ta'dib Vol. IV No. 02, September 2001.

"Shifting Paradigm Pendidikan Islam dalam Masyarakat Plural" dalam M. Amin Abdullah dkk., Tafsir Baru Studi Islam dalam Era Multikultural (Yogyakarta: IAIN Sunan Kalijaga dan KLS, 2002).

Peters, Michael dan Colin Lankshear, "Postmodern Counternarratives" dalam Henry Giroux, et al., Counternarratives Cultural Studies and Critical Pedagogies in Postmodern Spaces (New York \& London: Routledge, 1996).

Saiyidain, K.G., "Progressive Trends in Iqbal's Thought" in Eminent Scholars, Iqbal as A Thinker (Lahore: Sh. Muhammad Ashraf, 1991).

Sarantakos, Sotirios, Social Research, 2nd edition (Australia: Macmillan Education Australia Pty Ltd., 1998). 